\title{
Global economic value of shark ecotourism: implications for conservation
}

\author{
Andrés M. Cisneros-Montemayor, Michele Barnes-Mauthe \\ Dalal Al- Abdulrazzak, Estrella Navarro-Holmand U. Rashid Sumaila
}

\begin{abstract}
Amid declining shark populations because of overfishing, a burgeoning shark watching industry, already well established in some locations, generates benefits from shark protection. We compile reported economic benefits at shark watching locations and use a meta-analytical approach to estimate benefits at sites without available data. Results suggest that, globally, c. 590,000 shark watchers expend > USD 314 million per year, directly supporting 10,000 jobs. By comparison, the landed value of global shark fisheries is currently c. USD 630 million and has been in decline for most of the past decade. Based on current observed trends, numbers of shark watchers could more than double within the next 20 years, generating $>$ USD 780 million in tourist expenditures around the world. This supports optimistic projections at new sites, including those in an increasing number of shark sanctuaries established primarily for shark conservation and enacted in recognition of the ecological and economic importance of living sharks.
\end{abstract}

Keywords Economic value, fisheries, marine ecotourism, shark conservation

\section{Introduction}

$\mathrm{T}$ he near-exponential growth of global fishing capacity, coupled with high rates of bycatch and relatively slow population recovery rates, has resulted in the large-scale depletion of shark populations worldwide (Smith et al., 1998; Bonfil et al., 2005; Dulvy et al., 2008). According to FAO fisheries statistics $720,000 \mathrm{t}$ of sharks were landed in 2009; an independent estimate, based on the global shark fin trade alone, estimated c. 1.7 million t or c. 38 million sharks (Clarke et al., 2006). Given that not all captured sharks are destined for shark fin markets, and the occurrence of illegal, unregulated and unreported shark catches (Pramod et al.,

Andrés M. Cisneros-Montemayor (corresponding author), DAlal ALAbDulrazZaK and U. Rashid Sumaila Fisheries Centre, The University of British Columbia, Vancouver, British Columbia, V6L 1G2 Canada E-mail a.cisneros@fisheries.ubc.ca

Michele Barnes-Mauthe Department of Natural Resources and Environmental Management, University of Hawaii at Manoa, Honolulu, Hawaii, USA

Estrella Navarro-Holm Departamento de Biología Marina, Universidad Autónoma de Baja California Sur, La Paz, Baja California Sur, Mexico

Received 21 October 2012. Revision requested 16 November 2012. Accepted 16 November 2012. First published online zo May 2013.
2008), these figures are underestimates. The discrepancy between official and unofficial figures highlights the overall poor regulation of shark fisheries, including the common practice of shark-finning in the open seas, where oversight is low to nil (Chen \& Phipps, 2002), and the lack of knowledge on fishing statistics itself hinders management and conservation actions (Baum et al., 2003).

With the exception of some charismatic species such as whale sharks Rhincodon typus, elasmobranchs (cartilaginous fish) as a group have historically been overlooked in conservation, largely because of a lack of scientific data (Vannuccini, 1999) and a generally negative public image (Topelko \& Dearden, 2005; Maniguet, 2007). Nevertheless, thus far $>460$ shark and ray stocks have been assessed for the IUCN Red List, most with recent reviews (IUCN, 2013), with parallel efforts to document and assess global shark fisheries and populations underway (Biery et al., 2011). Although this is only a starting point, it reflects an increasing awareness by the public, governments, conservation groups and academics of the need for shark conservation.

Amid uncertainty about the future of shark populations there is a growing interest in the economic benefits of sharks for ecotourism at both local and global scales (Topelko \& Dearden 2005; Clua et al., 2011; Gallagher \& Hammerschlag, 2011). Some prominent shark watching sites are Ningaloo Reef, (Australia), Donsol (Philippines), Gansbaai (South Africa), Holbox Island (Mexico) and Gladden Spit (Belize; Irvine \& Keesing, 2007). As the diversity of these international locations suggests, the global distribution of sharks facilitates potential shark watching at many other sites. Economic benefits from shark watching are particularly evident at the local level (Gallagher \& Hammerschlag, 2011). For example, individual sharks in French Polynesia were estimated to have an ecotourism value of c. USD 1,200 per kg (based on data in Clua et al., 2011, and species lengthweight relationships), compared with a landed value to local fishers of USD 1.5 per $\mathrm{kg}$ for shark meat (Sumaila et al., 2007).

Although we recognize the value and achievements of shark conservation efforts from an ethical perspective, here we analyse the issue from the viewpoint of management of an economic resource, using specific performance metrics. We provide the first global estimate of the current and potential contribution of shark ecotourism in terms of tourist participation, tourist expenditures and employment, and make comparisons with shark landed value from 
fisheries. We focus on these metrics as they are the benefits captured by tourism operators or fishers, who, unlike final consumers, have the most to gain or lose from practices that trade off ecological degradation for economic benefits (Ransom \& Mangi, 2010).

\section{Methods}

Shark watching is defined here as any form of observing sharks in their natural habitat without intention to harm them. Unless otherwise specified, we use the term shark to refer to sharks, rays and chimaeras. Shark watching includes observation from boats, or underwater with snorkel or scuba gear (with or without luring them with bait), during day trips or longer tours. The performance indicators that we focus on are (1) participation (the number of people who participate in shark watching at a given site), (2) employment (the number of full-time equivalent jobs directly supported by shark watching tourism at a given site), and (3) expenditures (tourism expenditures wholly or partially attributable to watching sharks in a given location). All values presented are in USD, at 2011 value. We frame our global analysis in terms of FAO regions and subregions (FAO, 2011), which makes it easier to visualize, compute and compare estimates over a wide range of ecosystems and socio-economic conditions.

\section{Data collection}

We conducted an extensive review of the literature available on shark watching and shark fishing worldwide. These sources included peer-reviewed publications, government, NGO and newspaper reports, internet websites, UN databases and personal enquiries.

Firstly, we identified sites where dedicated shark watching, as opposed to chance encounters, is known to occur. Two sources of information were invaluable. The Shark Watcher's Handbook (Cawardine \& Watterson, 2002) provides in-depth documentation of $>260$ sites around the world where it is possible to watch sharks in the wild, and, in a global review of shark ecotourism, Gallagher \& Hammerschlag (2011) identify 83 shark watching sites of different types (e.g. general tourism, photography). We further screened sites to focus only on dedicated shark ecotourism and pooled some sites into more general locations (e.g. two individual dive spots at the same site are treated as one location) to facilitate data analysis.

This baseline information was complemented through extensive use of the search engines Google, Google Scholar, EBSCOHost, Academic Search Premier, Web of Science, and LexisNexis Academic, using the keywords shark, elasmobranch, fishing, fisheries, finning, conservation, tourism, ecotourism, watching, management, value, economic, tours, and diving. In addition, we contacted operators at several shark watching sites to obtain first-hand data on our selected indicators (participation, expenditures, employment) and asked them to suggest other operators they knew (i.e. snowball sampling). We continued our search until we were satisfied that all sites mentioned in our initial sources had been screened for potential data. In the case of live-aboard tours data were attributed to the site of departure rather than the destination site.

\section{Data analysis}

Given the paucity of site-specific data, a meta-analytical value-transfer method was used to estimate performance metrics in places where data were partially or wholly absent. Several authors have reviewed the methodology, uses and misuses of meta-analysis (e.g. Rosenthal \& DiMatteo, 2001; Shrestha \& Loomis, 2001). Within the meta-analytical framework the premise of the value-transfer approach is that, in the absence of site-specific data, values from similar sites (in this case, within the same FAO-defined subregion) can be used as proxies for interpolation. This makes the value-transfer approach a useful tool to analyse large-scale issues that have substantial data gaps.

If data were not available for an identified site we employed a relatively simple value-transfer approach to estimate indicators, as follows. If data on expenditure at a given site were available, but not the number of participants or jobs supported, the mean expenditure per capita for shark watching for sites with available data in the corresponding FAO subregion or region (in that order, depending on availability) was used to estimate the number of participants at the site. Because there were limited data available on employment, employment to expenditure ratios were assumed to be comparable to those of recreational fishing and whale watching tourism operations, which are similar in nature to shark watching operations. If necessary we used country-specific values calculated for recreational fishing and whale watching by Cisneros-Montemayor \& Sumaila (2010) to estimate employment.

In some instances no data on our indicators were available for identified shark watching sites. To estimate data for these sites we used a ranking system dependent on the scale of operations at each site compared to those with available data. Thus, sites were assigned a class; i.e. a number reflecting their size relative to others in the same subregion. For example, if the number of shark watchers was unknown for site $X$, it would be assigned the average number of shark watchers for sites in its subregion, multiplied by its class, for example 0.2, thereby assuming that the site had $20 \%$ as many shark watchers as others in the same subregion. Classes were initially assigned based on relative tourist arrivals to countries within each subregion (UN World Tourism Organization, 2011) and in some cases revised 
based on first-hand knowledge of relative participation at specific sites. In the case of large countries such as Australia, Canada and the USA we used state-, province- or territorylevel tourism arrivals. Revisions to classes always tended to the conservative side, under the assumption that sites without available data tend to be smaller in scale but should nonetheless be represented. Following this system, values for participation, expenditures and employment in shark watching were estimated for all identified sites around the world.

\section{Projected growth}

The classic tourism growth model follows a logistic pattern with discrete stages of establishment, development, consolidation and maturity (Butler, 1980) and has been extensively documented and tested against real data (Cole, 2009). To provide an estimate of potential future industry growth, we fitted a logistic model to available trend data to obtain the maximum (asymptote) value relative to current visitor numbers. Although future growth is expected for tourism in general (UN World Tourism Organization, 2011) we did not factor in the addition of new shark watching sites and thus our projection is conservative.

\section{Shark fisheries}

To contextualize the contribution of shark watching tourism at a global scale, key data on global shark fisheries, including landings, trade, and landed value, were compiled using FAO statistics (FAO, 2011), and species and countryspecific ex-vessel prices were compiled from Sumaila et al. (2007).

\section{Results}

\section{Shark watching}

We identified and focused data collection on 70 sites, within 45 countries, all five FAO regions, and 14 subregions (Fig. 1),

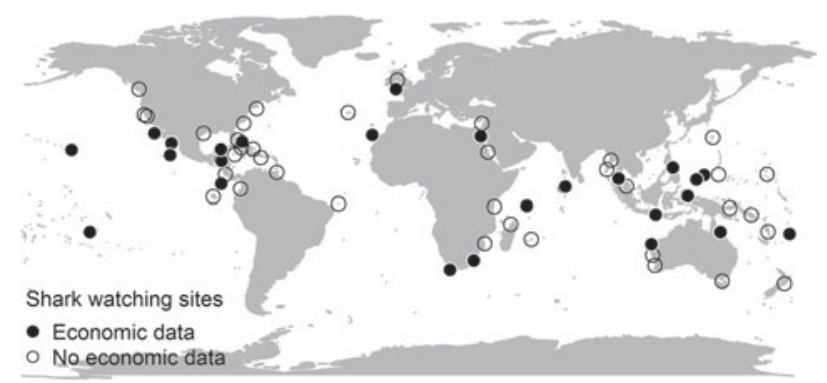

FIG. 1 Shark watching sites included in this study; filled circles denote sites with available economic data, open circles are sites with no available data. which were identified as overwhelmingly dedicated to shark watching for at least part of the year. Data were found for 31 sites, which provided the basis for subsequent estimations (sources cited in Table 1). In addition to interviews, data were also gathered from the peer-reviewed literature $(n=6)$, reports and conference proceedings $(n=5)$, government and NGO reports $(n=7)$ and one personal communication.

Our results suggest that every year $>590,000$ shark watchers at dedicated sites generate $>$ USD 314 million, supporting $>10,000$ jobs around the world. Our initial available data and estimation results are presented in Tables 1 and 2. Overall, there were four main groups of sites with respect to expenditure: $<$ USD 1 million per year $(n=25)$, USD 1-5 million $(\mathrm{n}=30)$, USD 5-10 million $(\mathrm{n}=9)$, and $>$ USD 10 million $(n=6)$. Sites with available expenditure data had a mean expenditure of USD 6.5 million per year, whereas sites with estimated data averaged USD 2.3 million per year.

TABLE 1 Locations (by country, in alphabetical order) with available data on annual shark watching expenditure (for countries with $>_{1}$ site, only available data are included here; i.e. no estimates are included). Shark landed values are total for the country using taxon-specific landings and price (based on data from Sumaila et al., 2007; data not available for Fiji, Honduras, Micronesia and Palau). All values are per year, in USD $\times 1,000$ (at the 2011 rate).

\begin{tabular}{lrc}
\hline Site & $\begin{array}{l}\text { Shark watching } \\
\text { expenditures }\end{array}$ & $\begin{array}{c}\text { Shark landed } \\
\text { value }\end{array}$ \\
\hline Australia $^{1,2,3}$ & 23,313 & 10,714 \\
Bahamas $^{4,5}$ & 82,267 & 0.1 \\
Belize $^{6}$ & 361 & 24 \\
Costa Rica $^{7}$ & 5,950 & 2,924 \\
Egypt $^{5}$ & 139 & 366 \\
Fiji $^{8}$ & 223 & \\
French Polynesia $^{9}$ & 5,404 & 220 \\
Honduras $^{5}$ & 144 & \\
Indonesia $^{3,5}$ & 4,058 & 58,030 \\
Maldives $^{10,11}$ & 11,334 & 525 \\
Micronesia $^{3}$ & 4,000 & 21,523 \\
Mexico $^{5,12,13}$ & 12,412 & \\
Palau $^{3,14}$ & 20,346 & 5,648 \\
Philippines $^{15}$ & 226 & 14 \\
Seychelles $^{15}$ & 3,470 & 44,437 \\
South Africa $^{16,17}$ & 6,074 & 12,362 \\
Spain $^{18}$ & 24,544 & 14,534 \\
Thailand $^{19}$ & 4,200 & 17,662 \\
United Kingdom $^{5}$ & 32 & 199,469 \\
USA $^{5,20}$ & 6,355 & \\
Total $^{5}$ & 214,852 & \\
\hline
\end{tabular}

Data sources: ${ }^{1}$ Stoeckl et al., 2010; ${ }^{2}$ Catlin et al., 2010; ${ }^{3}$ Heinrichs et al., 2011; ${ }^{4}$ Cline, 2008; ${ }^{5}$ This study; ${ }^{6} \mathrm{Carne}, 2008 ;{ }^{7} \mathrm{E}$. Sala, pers. comm.; ${ }^{8}$ Brunnschweiler, 2010; ${ }^{9}$ Clua et al., 2011; ${ }^{10}$ Anderson et al., 2010; ${ }^{11}$ Anderson \& Waheed, 2001; ${ }^{12}$ Iñiguez-Hernández, 2008; ${ }^{13}$ De la ParraVenegas, 2008; ${ }^{14}$ Vianna et al., 2010; ${ }^{15}$ Norman \& Catlin, 2007; ${ }^{16}$ Dicken \& Hosking, 2009; ${ }^{17}$ Hara et al., 2003; ${ }^{18}$ De la Cruz et al., 2010; ${ }^{19}$ Ziegler et al., 2008; ${ }^{20}$ Manta Pacific Research Foundation, 2007 (in Heinrichs et al., 2011) 
TABLE 2 Estimated annual economic benefits of shark watching by region (FAO, 2011). Expenditures are in USD (at the 2011 rate); employment is in full-time equivalents.

\begin{tabular}{lccc}
\hline & \multicolumn{3}{c}{ Shark } \\
Region & $\begin{array}{c}\text { Expenditure } \\
\text { watchers }\end{array}$ & \\
\hline Africa & $1,000$ s USD $)$ & $(1,000$ s $)$ & Employment \\
East Africa & 7,550 & 34 & 567 \\
North Africa & 840 & 3 & 331 \\
South Africa & 6,075 & 31 & 38 \\
Americas & 171,246 & 198 & 198 \\
Caribbean & 123,642 & 107 & 5,319 \\
Central America & 19,078 & 37 & 1,001 \\
North America & 15,405 & 43 & 138 \\
South America & 13,121 & 11 & 377 \\
Asia & 30,539 & 261 & 1,132 \\
East Asia & 3,187 & 2 & 79 \\
South-east Asia & 10,020 & 20 & 215 \\
South Asia & 6,075 & 237 & 717 \\
West Asia & 3,219 & 2 & 121 \\
Europe & 28,315 & 39 & 528 \\
Western Europe & 28,315 & 39 & 528 \\
Oceania & 69,785 & 58 & 1,625 \\
Australia \& & 39,908 & 29 & 267 \\
$\quad$ New Zealand & & & \\
Melanesia, & 29,877 & 29 & 1,358 \\
Micronesia, & & & \\
Polynesia & & & \\
Total & 314,352 & 590 & 10,671 \\
\hline
\end{tabular}

Dedicated shark watching concentrates on species that aggregate in specific temporal and spatial patterns and occur relatively close to the surface. The main species we identified were the whale shark, great white Carcharodon carcharias, tiger Galeocerco cuvier, angel Squatina spp., hammerhead Shpyrna spp., Galapagos Carcharhinus galapagensis, thresher Alopias spp., sandbar Carcharhinus plumbeus, basking Cetorhinus maximus and reef (Carcharhinus spp., Triaenodon spp.) sharks, and the manta (Manta birostris, Manta alfredi) and sting (Dasyatidae) rays.

Shark watching sites with information available on tourist arrivals had a mean yearly increase of $27 \%$ over the last 2 decades. Assuming logistic tourism growth the trend in total numbers of shark watchers (sum of available time series) was fitted to a logistic model to project future numbers. This resulted in an asymptote at c. 2.5 times current levels (Fig. 2). Within a range between current observed values and the projected increase, and assuming expenditure per capita remains constant, global shark watching could generate expenditures of USD 314-785 million within 20 years.

\section{Shark fisheries}

According to official statistics $>720,000 \mathrm{t}$ of sharks were landed in 2009, a $20 \%$ decline from the historical maximum

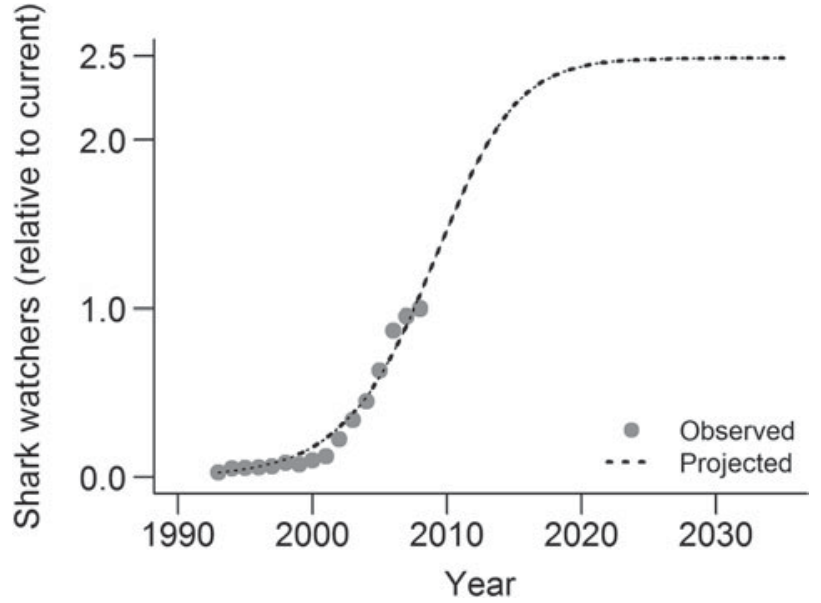

FIG. 2 Observed and projected total numbers of shark watchers at sites with trend information (Donsol, Philippines; Gladden Spit, Belize; Ningaloo, Australia; Holbox Island, Mexico). Estimates are the result of a logistic model fitted to observed data and extrapolated to estimated asymptote. All values are relative to 2008. Data sources: Cohun (2005), Remolina-Suárez et al. (2007), Pine (2007), Catlin et al. (2010).

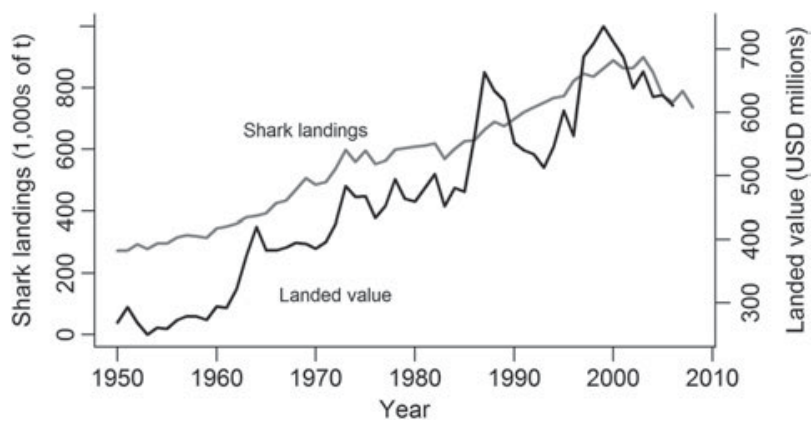

FIG. 3 Global shark landings and landed value (based on data from FAO, 2011, and Sumaila et al., 2007).

in 2003 and totalling c. USD 630 million in landed value (based on data from FAO, 2011, and Sumaila et al., 2007). Over $50 \%$ of all shark catches were made by the 10 countries (Indonesia, India, Spain, Taiwan, Mexico, Pakistan, Argentina, USA, Japan and Malaysia) with the highest average shark catches during the decade (Lack \& Sant, 2009). Although catches and landed value are declining (Fig. 3), global commodity trading of shark products has increased, largely as a result of increased demand from emerging Asian economies that value shark products, particularly shark fin soup, as luxury goods (Fig. 4).

\section{Discussion}

Shark watching as an economic activity has expanded globally (Fig. 1). The sum of expenditures at sites with available information is c. USD 215 million per year, which is more than the total landed value of sharks in the corresponding countries (Table 1). Our estimates, including 


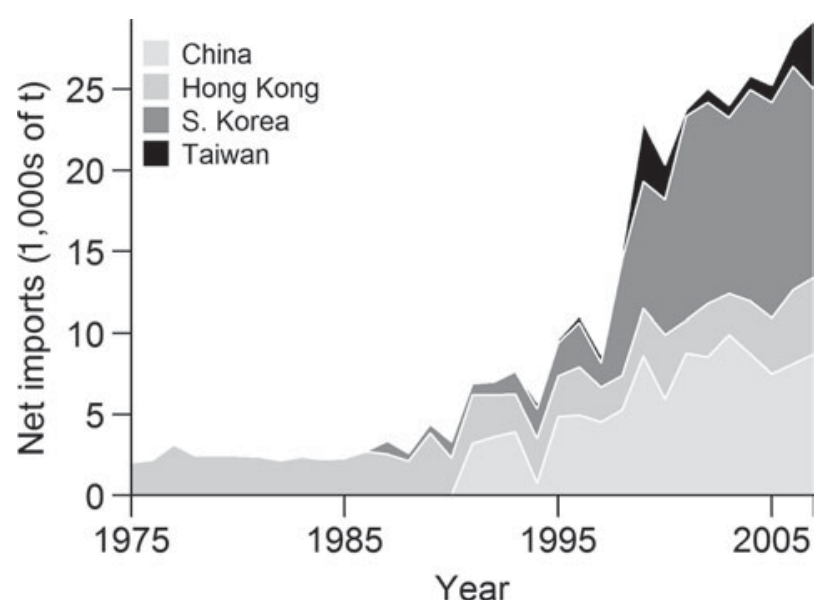

FIG. 4 Net imports of shark products in main Asian markets (based on data from FAO, 2011).

sites without available economic data, suggest that, globally, shark watching generates > USD 314 million, almost half the current value of global shark fisheries, and supports $>10,000$ jobs (Table 2).

There is a mean annual increase in visitors at shark watching sites of almost $30 \%$ during the last 20 years and visitor numbers should increase further as new sites become established. Based on observed growth trends, shark watching may attract 2.5 times as many visitors as today within 2 decades (Fig. 2), which would generate USD 785 million in direct visitor expenditures. Although this assumes constant expenditure per capita, real (inflation-adjusted) ticket prices at some sites have increased by $25 \%$ in the last decade, signalling increased demand from tourists (Gallagher \& Hammerschlag, 2011). Meanwhile, global shark landings and landed value have been steadily declining, mainly as a consequence of overfishing (Fig. 3). It is important to keep in mind that global shark fishing effort has increased and expanded spatially (Myers \& Worm, 2003; Swartz et al., 2010), making catch declines during the past decade of great concern. Furthermore, nearly all value from shark products is created in the luxury goods sector, particularly in Asian markets (Fig. 4). One bowl of shark fin soup may sell for $>$ USD 100 in Hong Kong but the average price paid to a fisher for a shark is c. USD $0.75 \mathrm{~kg}^{-1}$ (based on data in Sumaila et al., 2007).

Although there is an increasing number of documented shark watching operations, their economic contribution is unknown at many sites (Fig. 1), making estimates necessary for a global analysis. Although the limited quantity and type of data did not allow for proper sensitivity analyses, we have attempted to provide conservative estimates, recognizing uncertainty. Aside from possible errors in source data, the main potential error in our results is in the selection of sites to include in the estimation. In a review of global shark watching, Gallagher \& Hammerschlag (2011) identified 86 sites where shark watching occurs; under our criteria, only 70 sites were chosen. Our results are therefore conservative because at least some values would be estimated for any included site, although our method does avoid potential issues with sites where sharks are often seen but are not the central attraction for tourists. Sites with large shark watching operations tend to be over-represented in the literature, so our methods stressed conservative estimation. Using global subregions and relative tourist arrivals helped to mitigate potential upward bias in estimates for sites without data, with revisions to site class providing an additional check where necessary. Overall, sites with available data averaged c. USD 6.5 million in annual expenditures compared to c. USD 2.3 million for estimated sites.

The number of tourists (c. 590,000; Table 2) that currently participate in shark watching should be considered in the context of their impact. As a form of ecotourism, participation in shark watching is important because it can lead to increased awareness and support for conservation (Garrod \& Wilson, 2003; M. Barnes, unpubl. data), although this depends on how ecotourism operations are managed and implemented (Topelko \& Dearden, 2005). There are concerns regarding potential ecological impacts of ecotourism because of direct and indirect disturbance to organisms and habitat, including noise pollution (Williams et al., 2002) and damage to coral reefs (Davis \& Tisdell, 1995). In the case of shark watching, the practice of feeding sharks or chumming the water to attract them has been questioned because of possible effects on shark behaviour (Maljković \& Côté, 2010). Although well managed ecotourism sites have generally resulted in improved ecosystem health and structure, these potential negative effects must be considered to ensure that sites provide sustained benefits.

Sharks are widely distributed throughout the world's oceans and therefore shark watching can occur anywhere (Fig. 1). However, dedicated shark watching currently targets c. 10-20 species that are spatially and temporally accessible to humans (Gallagher \& Hammerschlag, 2011). The same traits that make some shark species amenable to tourism can also benefit conservation efforts because, charismatic appeal aside, species that aggregate in known temporal and spatial patterns, within sight of humans, may be easier to monitor and protect. This is especially true of species that aggregate near reefs or other fixed locations that can be designated as marine protected areas, providing a safe haven for shark populations at local and regional scales (Sala et al., 2002; Knip et al., 2012). Highly migratory shark species require other types of regulations, as even protected area networks may not be adequate (Lucifora et al., 2011). Reducing fishing mortality for overexploited species is a priority for any management framework that aims to achieve sustainable shark fisheries and conservation but we must design strategies for mortality reduction that are both effective and feasible. 
As the ecological and economic value of sharks is increasingly recognized, more areas primarily for conservation of sharks (commonly referred to as shark sanctuaries) are being established around the world, including almost 13 million $\mathrm{km}^{2}$ in the last 2 years alone, with some major players (i.e. Mexico, Taiwan) in global shark fisheries planning similar protection measures (Gronewold, 2011; Ho, 2011). Even relatively poor fishing communities, or those with important shark fisheries, may be amenable to conserving sharks given proper economic incentives, including the realization of sustainable income through shark watching ecotourism. The role of side payments, a form of benefit sharing in which tour operators pay a fee to adjacent fishing communities not to fish at specific reefs, has emerged as an interesting option in this context (e.g. Brunnschweiler, 2010). This type of strategy could be further explored in sites that have localized aggregations of sharks whose continued survival can benefit both fishers and tourism. Fishers can also enter the tourism industry themselves, as is occurring in several sites (e.g. Rossing, 2006; Irving \& Keesing, 2007). Although there are significant challenges to transitioning from fishing to tourism, the common theme in success stories is international attention and aid in the form of capacity building, including marketing strategies, customer service improvement and strong animal welfare guidelines, usually in the form of a code of conduct for tour operators.

Regarding the contribution of shark watching to the conservation of sharks, comparisons can be made with whale watching. The demise of the whaling industry, which has led to marked improvements in many whale populations, was sealed by prohibitions on catch but was also a result of decreased demand for whale products (Davis et al., 1988). However, the emergence of the global whale watching industry, currently generating $>$ USD 2 billion a year (O'Connor et al., 2009) and with potential for further growth (Cisneros-Montemayor et al., 2010), has added a new dimension to arguments in support of conservation and responsible resource use. Working to promote consumer awareness and support for sustainability is therefore vital (Jacquet \& Pauly, 2007), as increasing the number of environmentally aware tourists willing to pay to enjoy healthy ecosystems and shark populations will bring new economic options to coastal communities and both local and national governments.

Although not all shark species and/or sites lend themselves to tourism, those that do must be protected and invested in to secure sustainable economic benefits. Shark ecotourism cannot by itself provide conservation incentives to all fishers, particularly where sharks migrate or move seasonally. However, it is an increasingly important industry, with high potential for further growth. Together with more effective controls on global fisheries and an added focus on consumer awareness of unsustainable fishing practices, shark watching could prove crucial for the future status of shark populations. The potential and realized benefits of shark watching will thus depend on the actions and decisions of coastal communities and governments, with an increasingly real economic incentive for conservation.

\section{Acknowledgements}

We would like to thank Mary O'Malley of Shark Savers, Stefanie Brendl of WildAid and Hawaii Shark Encounters, Celia Faircloth at Hawaii Shark Encounters, Joe Pavsek of North Shore Shark Adventures, Richard Peirce of the Shark Conservation Society, Steve Fox at Deep Blue Utila, Jim Abernethy, Charles Hood, Mauricio Handler, Hannah Jones, Wilf Swartz (University of British Columbia), Mariana Walther (University of Queensland, Australia), Enric Sala (National Geographic Society) and others who contributed to this study with data, insights, suggestions and comments. We thank the Pew Charitable Trusts for their financial support.

\section{References}

Anderson, C. \& Waheed, A. (2001) The economics of shark and ray watching in the Maldives. Shark News, 13, 1-3. Http://www.iucnssg. org/tl_files/Assets/pdf/SN/SN13\%2oLOW\%20RES.pdf [accessed 18 March 2013].

Anderson, R.C., Shiham Adam, M., Kitchen-Wheeler, A.M. \& STEvens, G. (2010) Extent and economic value of manta ray watching in Maldives. Tourism in Marine Environment, 7, 15-27.

Baum, J.K., Myers, R.A., Kehler, D.G., Worm, B., Harley, S.J. \& Doherty, P.A. (2003) Collapse and conservation of shark populations in the Northwest Atlantic. Science, 299, 389-392.

Biery, L., Palomares, M.L.D., Morisette, L., Cheung, W.W.L., Harper, S., Jacquet, J. et al. (2011) Sharks in the Seas Around Us: How the Sea Around Us Project is Working to Shape our Collective Understanding of Global Shark Fisheries. A report prepared for the Pew Environment Group by the Sea Around Us Project. Fisheries Centre, The University of British Columbia, Vancouver, Canada.

Bonfil, R., Meyer, M., Scholl, M.C., Johnson, R., O’Brien, S., Oosthuizen, H. et al. (2005) Transoceanic migration, spatial dynamics and population linkages of white sharks. Science, 310, 100.

Brunnschweiler, J.M. (2010) The Shark Reef Marine Reserve: a marine tourism project in Fiji involving local communities. Journal of Sustainable Tourism, 18, 29-42.

BUtLER, R. (1980) The concept of a tourism area life cycle of evolution: implications for management of resources. Canadian Geographer, 24, 5-12.

CARne, L. (2008) Monitoring and management of whale shark tourism at Gladden Spit and the Silk Cayes Marine Reserve, Belize, 2003-2007. Presentation at the Second International Whale Shark Conference, Holbox, Mexico, July 2008. Http://www.domino.conanp.gob.mx/ doc_conf/Lisa.pdf [accessed 27 February 2013].

Catlin, J., Jones, T., Norman, B. \& Wood, D. (2010) Consolidation in a wildlife tourism industry: the changing impact of whale shark tourist expenditure in the Ningaloo coastal region. International Journal of Tourism Research, 12, 134-148. 
Camardine, M. \& Watterson, K. (2002) The Shark Watcher's Handbook: A Guide to Sharks and Where to See Them. Princeton University Press, Princeton, USA.

Chen, V.Y. \& Phipps, M.J. (2002) Management and Trade of Whale Sharks in Taiwan. A TRAFFIC East Asia Report. Http://www.traffic. org/species-reports/traffic_species_fish9.pdf [accessed 5 March 2013].

Cisneros-Montemayor, A.M. \& Sumaila, U.R. (2010) A global estimate of benefits from ecosystem-based marine recreation potential impacts and implications for management. Journal of Bioeconomics, 12, 245-268.

Cisneros-Montemayor, A.M., Sumaila, U.R., Kaschner, K. \& PAUly, D. (2010) The global potential for whale watching. Marine Policy, 34, 1273-1278.

Clarke, S.C., McAllister, M.K., Milner-Gulland, E.J., Kirkwood, G.P., Michielsens, C.G.J., Agnew, D.J. et al. (2006) Global estimates of shark catches using trade records from commercial markets. Ecology Letters, 9, 1115-1126.

Cline, W. (2008) Shark Diving Overview for the Islands of the Bahamas. Report of the Bahamas Ministry of Tourism, Nassau, Bahamas.

Clua, E., Burray, N., Legendre, P., Mourier, J. \& Planes, S. (2011) Business partner or simple catch? The economic value of the sicklefin lemon shark in French Polynesia. Marine and Freshwater Research, 62, 764-770.

Cohun, K. (2005) Managing the Gladden Spit Marine Reserve: An Analysis of the Whale Shark Dive Tourism Industry in Placencia, Belize. MSc thesis. Duke University, Durham, USA.

Cole, S. (2009) A logistic tourism model. Resort cycles, globalization and chaos. Annals of Tourism Research, 36, 669-714.

Davis, D. \& Tisdell, C. (1995) Recreational scuba-diving and carrying capacity in marine protected areas. Ocean and Coastal Management, 26, 19-40.

Davis, L.E., Gallman, R.E. \& Hutchins, T.D. (1988) The decline of U.S. whaling: was the stock of whales running out? Business History Review, 62, 569-595.

Dicken, M.L. \& Hosking, S.G. (2009) Socio-economic aspects for the tiger shark diving industry within the Aliwal Shoal Marine Protected Area, South Africa. African Journal of Marine Science, 31, 227-232.

De La Cruz-Modino, R., Esteban, R., Crilly, R. \& Pascual-Fernández, J. (2010) Bucear con tiburones y rayas en España. Análisis de su potencial en España y de los beneficios económicos de la actividad en las Islas Canarias. Instituto Universitario de Ciencias Políticas y Sociales de la Universidad de La Laguna y Nef, Santa Cruz de Tenerife, Spain.

De La Parra-Venegas, R. (2008) Proyecto Dominó. Informe Técnico General, 2003-2008. Http://www.domino.conanp.gob.mx/ actualizacion\%2ode\%2oresultados\%202003\%20-\%202008.pdf [accessed 27 February 2013].

Dulvy, N.K., Baum, J.K., Clarke, S., Compagno, L.J.V., Cortés, E., Domingo, A. et al. (2008) You can swim but you can't hide: the global status and conservation of oceanic pelagic sharks and rays. Aquatic Conservation: Marine and Freshwater Ecosystems, 18, $459-482$

FAO (2011) Fisheries Statistics and Information. Fisheries and Aquaculture Department, Food and Agriculture Organization of the UN, Rome, Italy. Http://www.fao.org/fishery [accessed 5 March 2013].

Gallagher, A. \& Hammerschlag, N. (2011) Global shark currency: the distribution, frequency and economic value of shark ecotourism. Current Issues in Tourism, 1, 1-6.

Garrod, B. \& Wilson, J. (2003) Aspects of Tourism: Marine Ecotourism, Issues and Experiences. Channel View Publications, Clevedon, UK.
Gronewold, N. (2011) Mexico will ban shark fishing as global sanctuary movement grows. New York Times, 23 September 2011. Http://www.nytimes.com/gwire/2011/o9/23/23greenwire-mexicowill-ban-shark-fishing-as-global-sanctu-29510.html [accessed 27 February 2013].

Hara, M., Maharaj, I. \& Pithers, L. (2003) Marine-based tourism in Gansbaai: a socio-economic study. Prepared for the Department of Environmental Affairs by Programme for Land and Agrarian Studies, University of the Western Cape, Bellville, South Africa. Http://sharkxplorers.com/pdf/gansbaai.pdf [accessed 21 November 2011].

Heinrichs, S., O'Malley, M., Medd, H. \& Hilton, P. (2011) The Global State of Manta and Mobula Rays. Http://www.sharksavers. org/images/stories/documents/The\%20Global\%20Threat\%2oto\% 20Manta\%20and\%20Mobula\%2oRays.pdf [accessed 2 February 2012].

Ho, E. (2011) Taiwan to become first Asian nation to ban shark finning. Time, 1 December 2011. Http://newsfeed.time.com/2011/12/o1/ taiwan-to-become-first-asian-nation-to-ban-shark-finning [accessed 1 December 2011].

Iñiguez-Hernández, L. (2008) Diagnóstico de la actividad turística desarrollada con tiburón blanco Carcharodon carcharias en Isla Guadalupe, Baja California. MSc thesis. Universidad Autónoma de Baja California, La Paz, Mexico.

IRVINE, T.R. \& KeEsING, J.K. (eds) (2007) The First International Whale Shark Conference: Promoting International Collaboration in Whale Shark Conservation, Science and Management. Conference Overview, Abstracts and Supplementary Proceedings. CSIRO Marine and Atmospheric Research, Western Australia, Australia.

IUCN (2013) IUCN Red List of Threatened Species Http://www. iucnredlist.org [accessed 27 February 2013].

JACQUeT, J.L. \& PAULY, D. (2007) The rise of seafood awareness campaigns in an era of collapsing fisheries. Marine Policy, 31, 308-313.

Knip, D.M., Heupel, M.R. \& Simpfendorfer, C.A. (2012) Evaluating marine protected areas for the conservation of tropical coastal sharks. Biological Conservation, 148, 200-209.

LACK, M. \& SANT, G. (2009) Trends in Global Shark Catch and Recent Developments in Management. TRAFFIC International. Http:// www.traffic.org/species-reports/traffic_species_fish34.pdf [accessed 7 November 2011].

Lucifora, L.O., García, V.B. \& Worm, B. (2011) Global diversity hotspots and conservation priorities for sharks. PLOS ONE, 6, e19356.

MaljKović, A. \& Côté, I.M. (2010) Effects of tourism-related provisioning on the trophic signatures and movement patterns of an apex predator, the Caribbean reef shark. Biological Conservation, $144,859-865$.

Maniguet, X. (2007) The Jaws of Death: Sharks as Predator, Man as Prey. Skyhorse Publishing, New York, USA.

Manta Pacific Research Foundation (2007) Manta Economics Survey of Kailua-Kona, Hawaii Dive and Snorkel Operators. Manta Pacific Research Foundation, Kailua-Kona, Hawaii, USA.

Myers, R.A. \& Worm, B. (2003) Rapid worldwide depletion of predatory fish communities. Nature, 423, 280-283.

Norman, B. \& Catlin, J. (2007) Economic Importance of Conserving Whale Sharks. Report for the International Fund for Animal Welfare, Sydney, Australia. Http://www.whalesharkfest.com/pdf/ economicimportance.pdf [accessed 2 February 2012].

O’Connor, S., Campbell, R., Cortez, H. \& Knowles, T. (2009) Whale Watching Worldwide: Tourism Numbers, Expenditures and Expanding Economic Benefits. A Special Report from the International Fund for Animal Welfare. International Fund for Animal Welfare, Yarmouth, USA, prepared by Economists at Large. 
PINE, R. (2007) Donsol Whale Shark Tourism and Coastal Resource Management. A Case Study in the Philippines. WWF, Quezon City, Philippines.

Pramod, G., Pitcher, T.J., Pearce, J. \& Agnew, D. (2008) Sources of information supporting estimates of unreported fishery catches (IUU) for 59 countries and the high seas. Fisheries Centre Research Report, 16, 242.

Ransom, K.P. \& MANGI, S.C. (2010) Valuing recreational benefits of coral reefs: the case of Mombasa Marine National Park and Reserve, Kenya. Environment Management, 45, 145-154.

Remolina-Suárez, J.F., Pérez-Ramírez, J.J., González-Cano, J.M., De la Parra-Venegas, R., Betancourt-Sabatini, N., Trigo-Mendoza, M. et al. (2007) Whale shark management strategies, with the participation of local stakeholders, in Yum Balam, Mexico. In The First International Whale Shark Conference: Promoting International Collaboration in Whale Shark Conservation, Science and Management. Conference Overview, Abstracts and Supplementary Proceedings (eds T.R. Irvine \& J.K. Keesing), pp. 31-35. CSIRO Marine and Atmospheric Research, Western Australia.

Rosenthal, R. \& DiMatteo, M.R. (2001) Meta-analysis: recent developments in quantitative methods for literature reviews. Annual Review of Psychology, 52, 59-82.

Rossing, P.A. (2006) Evaluating ecotourism in Mexico's biosphere reserves-Whale watching activities in the world heritage site of Laguna San Ignacio, Baja California Sur, Mexico 1994-2002. MSc thesis. The University of British Columbia, Vancouver, Canada.

Sala, E., Aburto-Oropeza, O., Paredes, G., Parra, I., Barrera, J. C. \& DAYTON, P.K. (2002) A general model for designing networks of marine reserves. Science, 298, 1991-1993.

Shrestha, R.K. \& Loomis, J.B. (2001) Testing a meta-analysis model for benefit transfer in international outdoor recreation. Ecological Economics, 39, 67-83.

Smith, S.E., Au, D.W. \& SHow, C. (1998) Intrinsic rebound potentials of 26 species of Pacific sharks. Marine and Freshwater Research, 49, 663-678.

Stoeckl, N., Birtles, A., Farr, M., Mangott, A., Curnock, M. \& Valentine, P. (2010) Live-aboard dive boats in the Great Barrier reef: regional economic impact and the relative values of their target marine species. Tourism Economics, 16, 995-1018.

Sumaila, U.R., Marsden, A.D., Watson, R. \& Pauly, D. (2007) A global ex-vessel price database: construction and applications. Journal of Bioeconomics, 9, 39-51.
Swartz, W., Sala, E., Tracey, S., Watson, R. \& Pauly, D. (2010) The spatial expansion and ecological footprint of fisheries (1950 to present). PLoS ONE, 5, e15143.

Topelko, K.N. \& Dearden, P. (2005) The shark watching industry and its potential contribution to conservation. Journal of Ecotourism, 4, 108-128.

UN World Tourism Organization (2011) Http://www2.unwto.org [accessed 27 February 2013].

Vannuccini, S. (1999) Shark Utilization, Marketing and Trade. FAO Fisheries Technical Paper No. 389. Food and Agriculture Organization of the UN, Rome, Italy.

Vianna, G.M.S., Meekan, M.G., Pannell, D., Marsh, S. \& Meeuwig, J.J. (2010) Wanted Dead or Alive? The Relative Value of Reef Sharks as a Fishery and an Ecotourism Asset in Palau. Australian Institute of Marine Science and University of Western Australia, Perth, Australia.

Williams, R., Trites, A.W. \& Bain, D.E. (2002) Behavioural responses of killer whales (Orcinus orca) to whale-watching boats: opportunistic observations and experimental approaches. Journal of Zoology, 256, 255-270.

Ziegler, J., Dearden, P., Catlin, J. \& Norman, B. (2008) Assessing the sustainability of global shark tourism: global perspective. Presentation at the Second International Whale Shark Conference, Holbox, Mexico, July 2008. Http://www.domino.conanp.gob.mx/ doc_conf/Jackie.pdf [accessed 27 February 2013].

\section{Biographical sketches}

Andrés Cisneros-Montemayor is a marine resource economist who specializes in ecosystem approaches to fisheries and ecotourism management. His work focuses on sustainable development at global and local scales. Michele Barnes-Mauthe is an interdisciplinary social scientist who specializes in marine resource socio-economics. Her work seeks to contribute to a more thorough integration of the social and economic components of marine resource systems to achieve long-term sustainability and conservation. DALAL ALABDULRAZZAK is a marine ecologist specializing in long-term changes in the ecology and fisheries of the Persian Gulf. Estrella NAVARRO-Holm is a marine biologist who specializes in shark biology and ecology. She is involved with media outreach work to foster marine conservation, including television and documentary collaborations with the $\mathrm{BBC}$ and the Travel Channel. RASHiD SUMAILA is interested in how economics, through integration with ecology and other disciplines, can be used to help ensure that environmental resources are sustainably managed. 